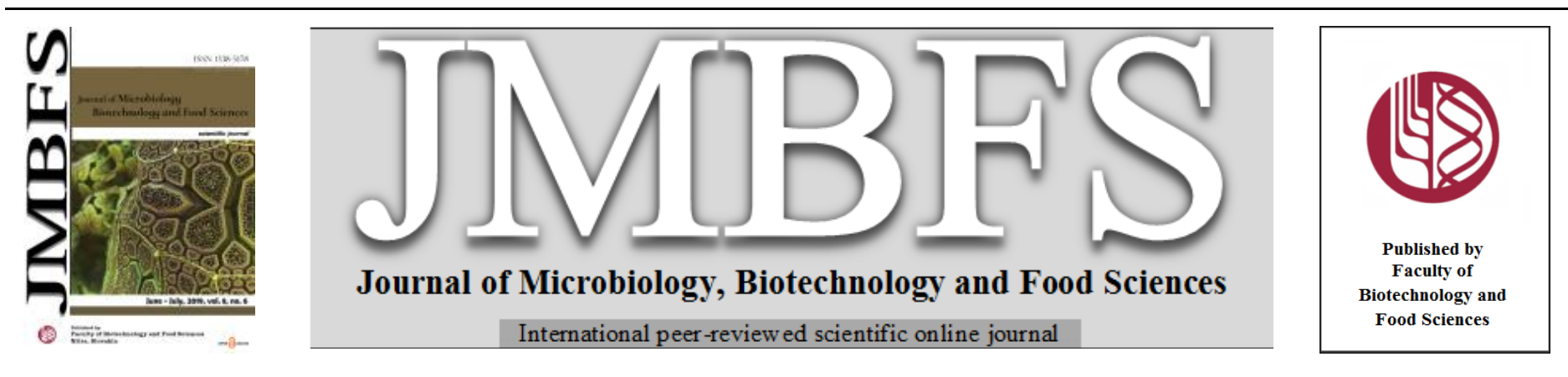

\title{
IDENTIFICATION OF VIRULENCE GENES, $\beta$-LACTAMS AND QUINOLONES RESISTANCE-ASSOCIATED GENES AND INTEGRONS IN SALMONELLA ISOLATED FROM RETAIL CHICKEN MEAT AND GIBLETS IN EGYPT
}

\author{
Abdelrahim H.A. Hassan ${ }^{*}$, Hala S.H. Salam ${ }^{2}$ and Gihan K. Abdel-Latef \\ Address(es): \\ ${ }^{1}$ Department of Food Hygiene and Control, Faculty of Veterinary Medicine, Beni-Suef University, Beni-Suef 62511, Egypt. \\ ${ }^{2}$ Department of Bacteriology, Mycology and Immunology, Faculty of Veterinary Medicine, Beni-Suef University, Beni-Suef 62511, Egypt. \\ ${ }^{3}$ Department of Hygiene, Zoonoses and Epidemiology; Faculty of Veterinary Medicine, Beni-Suef University, Beni-Suef 62511, Egypt.
}

*Corresponding author: abdelrahim@vet.bsu.edu.eg

doi: 10.15414/jmbfs.2019.8.6.1320-1325

ARTICLE INFO

Received 25. 10. 2018

Revised 6. 2. 2019

Accepted 20. 2. 2019

Published 1. 6. 2019

Regular article

open $\partial_{\text {ACCESS }}$

\begin{abstract}
The study investigated the prevalence of virulent and antibiotic resistant Salmonella (S) in retail chicken meat (CM) and pooled giblets (PG) in Egypt. Seventy-two and $64 \%$ of examined CM and PG samples harbored Salmonellae, respectively. When S. Infantis was the most predominant serovar, followed by S. Kentucky, and then S. Virchow. The antibiotic resistance experiment showed a high rate of multiple drug resistant (MDR) Salmonellae. Remarkably, 64.7\% of the isolates were resistant to ciprofloxacin (the drug of choice for Salmonella infection). Molecularly, a noteworthy correlation between the MDR and the presence of integrons class 1 and 3. When, integrons 1 and 3 were detected in 100 and $92 \%$ of identified MDR isolates, respectively, while class 2 integrons were not found. Surprisingly, 53.8 and $100 \%$ of the molecularly identified isolates were resistant to ciprofloxacin and nalidixic acid, despite the absence of plasmid-mediated quinolone resistance (PMQR)-associated genes ( $q n r A, q n r B$ and $q n r S, a a c\left(6^{\prime}\right)-I b-c r$ and $q e p A$ ) from all MDR isolates. This indicates that other genetic factors could be incriminated in this pattern. Beta-lactam resistance was explored by the existence of $b a_{\mathrm{TEM}}, b l a_{\mathrm{CTX}}$, and bla $a_{\mathrm{CMY}-2}$ genes in most MDR isolates. Additionally, 4 virulence genes were detected in almost all serovars. Concerning virulence genes, invA, hilA, $\operatorname{sop} B$, and $\sin$ were detected in 100, 100, 100 and $94.7 \%$ of MDR serovars, respectively. While, $s p v C$ was detected in only $7.6 \%$, and pef was absent. The high prevalence of MDR virulent Salmonella strains in retail chicken meat and giblets in Egypt should be faced with a great worry, as consumers could be under a great public health risk.
\end{abstract}

Keywords: Salmonella, Foodborne pathogens, zoonoses, antibiotic resistance, integrons, virulence genes

\section{INTRODUCTION}

The genus Salmonella $(\mathrm{S})$, an Enterobacteriaceae member, is facultative aerobic intracellular bacteria that capable of causing varieties of illnesses in a wide range of hosts. Salmonella has been recognized as the leading cause of foodborne diseases in human, leading to 1.3 billion cases of gastroenteritis, 16 million cases of typhoid infection, and about 3 million deaths around the globe every year (Bhunia, 2007). A variety of food items have been incriminated in human Salmonellosis outbreaks, especially those derived from animals such as beef, pork, poultry, and eggs. Nevertheless, poultry and poultry products are the most associated foods with Salmonella outbreaks in humans (EFSA and ECDC, 2013; Antunes et al., 2016).

Most of Salmonella food poisoning outbreaks are caused by Salmonella enterica subspecies enterica, though, over 2,500 Salmonella serovars have been identified and new serovars are designated frequently (Hassan et al., 2015). The pathogenicity of Salmonella is managed by several factors established by virulence genes that enable the pathogen to express its virulence in the host and eventually produce the characteristic symptoms of the disease, besides, antibiotic resistance-associated genes. The invasion gene invA is unique for the genus Salmonella, so it represents a suitable DNA target in diagnostic approaches. invA is situated in Salmonella pathogenicity islands coding to produce certain proteins, which are accountable for the invasion of the pathogen into the host cells (Valdez et al., 2009). Plasmid-encoded fimbria (pef) locus assists the bacteria to adhere to the intestinal epithelial cells (Friedrich et al., 1993), and $s p v$ is another plasmidlocated virulence gene, which suppresses host innate immune system to bacterial infection (Yang et al., 2016). Salmonella outer proteins (sop A-E) encoded with sop gene are responsible for the pathogen penetration through cell membrane deformities and rearrangement of the host cell cytoskeletons (Borges et al., 2013), besides hilA, which is considered a hyper invasive locus (Lostroh et al., 2000). While, the virulence gene stn arbitrates the production of enterotoxins and was found to be linked to causing acute gastroenteritis in infected hosts (Zou et al., 2012).
In addition to virulence, the emergence of antibiotic resistant strains of Salmonella has become a significant public health risk. It was found that the improper application of antibiotics in livestock production for preventive and therapeutic purposes, as well as growth promotion is a noteworthy factor in appearance of antibiotic resistant bacteria in animals and poultry. These resistant bacteria which is subsequently transferred to human through food chain is challenging the efforts of serving safe food for consumers (Antunes et al., 2016). Factors related to the antibiotic resistance and virulence of Salmonella may be situated on chromosomes, plasmids, integrons and transposon. Integrons are genetic elements that play an important role in the dissemination of resistance genes between bacteria owing to the associated conjugative plasmids. There are two main groups of integrons: mobile integrons and chromosomal integrons (Cambray et al., 2010). Based on the sequence of the encoded integrases, five different classes of mobile integrons have been identified. Even though, only classes 1, 2, and 3 have been reported in the spread of multidrug-resistance phenotypes, all 5 classes have been associated with antibiotic-resistance determinants (Siriken et al., 2015). Furthermore, several non integron-related resistance genes have also been reported in Salmonella; such as quinolones resistance determinants ( $q n r A, q n r B, q n r S$, aac $\left.\left(6^{\prime}\right)-I b-c r, q e p A\right)$ and $\beta$-lactams resistance-related genes (bla $a_{\mathrm{TEM}}$, bla $_{\mathrm{CTX}}$, and bla $a_{\mathrm{CMY}-2}$ ) (Robicsek et al., 2006; Wiesner et al., 2016). Accordingly, the identification of virulence genes, antibiotic resistance genes and integrons in Salmonella isolates from retail chicken became a very crucial approach for risk assessment of such pathogen in this food item.

Therefore, the present study was conducted to estimate the prevalence and antibiotic susceptibility/resistance of Salmonella species from retail chicken meat (CM) and pooled giblets (PG) in Beni-Suef governorate, Egypt, beside serological identification of the isolates. As well as, molecular identification of virulence genes, $\beta$-lactams and quinolones resistance-associated determinants and integrons (classes 1, 2, and 3) using Polymerase Chain Reaction (PCR). 


\section{MATERIALS AND METHODS}

\section{Sample collection}

A total of 50 broiler chicken carcasses (around 40 days age at time of slaughtering) were randomly collected from retail poultry outlets in Beni-Suef governorate, Egypt during 2016 - 2017. All carcasses were purchased in fresh state directly after slaughtering in the retail market. Each carcass was represented by a specimen from muscle as chicken meat (CM) and another from gizzard, liver, and heart as pooled giblets (PG), with a total of 100 samples (50 CM and $50 \mathrm{PG}$ ). The collected samples were identified and wrapped separately in sterile polyethylene bags to be directly transferred without delay in an icebox to the laboratory for further preparation and examination.

\section{Isolation and identification of Salmonella}

Isolation and morphological and biochemical identification of Salmonella spp. from CM and PG was done according to the standard protocol of ISO 6579 (2002). Briefly, $25 \mathrm{~g}$ specimen was aseptically removed from each CM and PG of each carcass, and then homogenized with $225 \mathrm{~mL}$ of $0.1 \%$ sterile buffered peptone water (Biolife; Italy). Afterwards, the homogenate was incubated at $36 \pm$ $1{ }^{\circ} \mathrm{C}$ for $16-20 \mathrm{~h}$. Then 0.1 and one $\mathrm{mL}$ of the pre-enrichment broth were inoculated into $10 \mathrm{~mL}$ of Rappaport-Vassiliadis (RV) broth (Biolife; Italy) and 10 $\mathrm{mL}$ of Müller-Kaufmann Tetrathionate (MKT) broth (Biolife; Italy), respectively. The enrichment broths were further incubated at $41.5 \pm 0.5^{\circ} \mathrm{C}$ (for RV) and $36 \pm$ $1{ }^{\circ} \mathrm{C}$ (for MKT) during 18-24 h. A loopful from each broth after incubation was streaked onto each of Salmonella-Shigella (SS) and Xylose Lysine Desoxycholate (XLD) agar plates and incubated at $36 \pm 1{ }^{\circ} \mathrm{C}$ for $18-24 \mathrm{~h}$ Colorless colonies with black centers on SS and slightly transparent red colonies with black center on XLD agar plates were suspected as Salmonella and selected for further identification procedures. Suspected colonies of Salmonella were identified morphologically by Gram`s staining, and biochemically by oxidase, indole, methyl red, voges proskauer, citrate utilization, triple sugar iron (TSI) and urease tests. All morphologically and biochemically confirmed Salmonella isolates were consequently identified by serology based on somatic (O) and flagellar $(\mathrm{H})$ antigens by slide agglutination using commercial antisera (SISIN, Berlin) following the Kauffman-White scheme (Popoff et al., 2004). See the schematic protocol in Figure 1.

\section{Antibiotic sensitivity/resistance testing}

All serologically identified Salmonella enterica subspecies enterica serovars were tested for their antibiotic susceptibility pattern by disc diffusion technique according to the Clinical and Laboratory Standards Institute, CLSI (2018) Commercial discs of antibiotic (Oxoid, UK) soaked with cefotaxime $(30 \mu \mathrm{g})$, ampicillin $(10 \mu \mathrm{g})$, ciprofloxacin $(5 \mu \mathrm{g})$, ceftazidime $(30 \mu \mathrm{g})$, amikacin $(30 \mu \mathrm{g})$, piperacillin-tazobactam $(100 / 10 \mu \mathrm{g})$, amoxicillin-clavulanic acid $(20 / 10 \mu \mathrm{g})$, nalidixic acid $(30 \mu \mathrm{g})$, aztreonam $(30 \mu \mathrm{g})$, and tetracycline $(30 \mu \mathrm{g})$ (Oxoid, UK) were used. Multidrug resistant isolate (MDR) is defined as that isolate resist three or more antibiotics belonging to different antibiotic categories.

\section{Molecular detection of Salmonella virulence genes and integrons using PCR}

MDR Salmonella serovars were molecularly identified for the presence of 6 virulence genes (hilA, stn, pef, invA, sopB and spvC), 8 antibiotic resistance determinants, out of them, 5 are linked to quinolones resistance ( $q n r A, q n r B$, $q n r S, a a c\left(6^{\circ}\right)-I b-c r$ and $\left.q e p A\right)$ and the rest three antibiotic resistance genes are related to beta-lactams resistance (bla $a_{\mathrm{TEM}}, b_{\mathrm{CMY}_{\mathrm{C}-2}}$ and $\left.b l a_{\mathrm{CTX}}\right)$, in addition to identification of integrons classes 1,2 and 3. Genomic DNA was extracted from overnight bacterial cultures using Qiagen DNA extraction kit (Qiagen, Germany) according to the manufacturer's instructions. Specific primers obtained from Metabion (Germany) for each target gene were used for DNA amplification using uniplex PCR. The sequences of primers and sizes of amplified segments are listed in Table 1. Primers were utilized in a $25 \mu \mathrm{L}$ reaction tube containing 12.5 $\mu \mathrm{L}$ of Emerald Amp Max PCR Master Mix (Takara, Japan), $1 \mu \mathrm{L}$ of each primer of 20 pmol concentrations, $6 \mu \mathrm{L}$ of DNA template, and $4.5 \mu \mathrm{L}$ of nuclease free water. The reactions were performed in an Applied Biosystem 2720 thermal cycler. Briefly, initial denaturation step was done at $94{ }^{\circ} \mathrm{C}$ for $5 \mathrm{~min}$, then followed by 35 cycles of $94{ }^{\circ} \mathrm{C}$ for $45 \mathrm{sec}$, afterwards, $40 \mathrm{sec}$ of annealing was applied according to the temperatures showed in Table 1. Subsequently, an extension step at $72{ }^{\circ} \mathrm{C}$ for $45 \mathrm{sec}$ and a final extension step at $72{ }^{\circ} \mathrm{C}$ for $10 \mathrm{~min}$ were conducted. The products of PCR were separated by electrophoresis on $1.5 \%$ agarose gel (Applichem, Germany, GmbH) in 1x TBE buffer at room temperature using gradients of $5 \mathrm{~V} / \mathrm{cm} .20 \mu \mathrm{L}$ of the PCR products were loaded in each gel slot. The fragment sizes were determined using Gelpilot $100 \mathrm{bp}$ and 100 bp plus DNA Ladders (Qiagen, Germany, GmbH) and Gene ruler 100 bp ladder (Thermo Scientific, Germany). Afterwards, the gel was photographed by a gel documentation system (Alpha Innotech, Biometra).

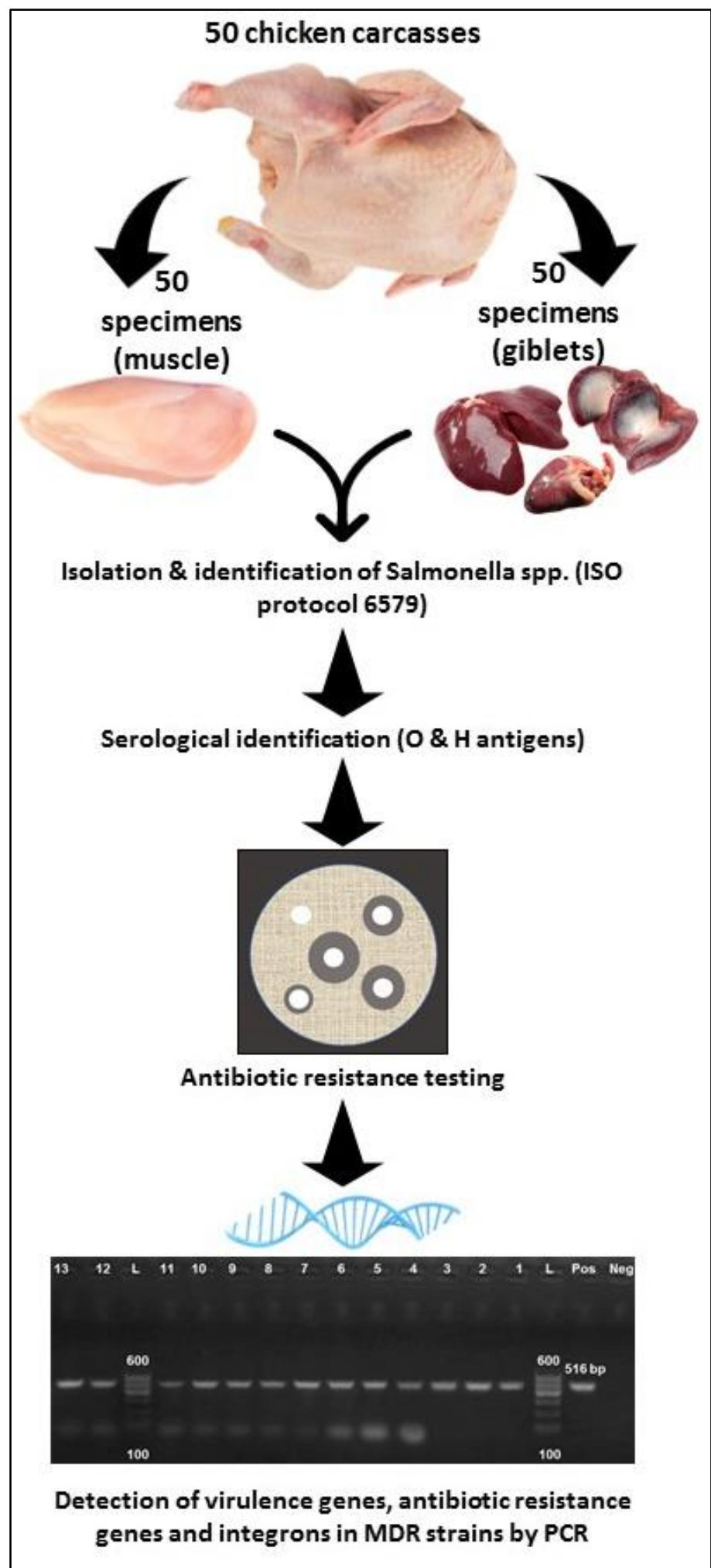

Figure 1 Schematic protocol of detailed procedures of Salmonella isolation, identification and antibiotic resistance testing during the study. MDR (multidrug resistant). 
Table 1 Primers sequences of target genes, amplicon sizes and annealing temperatures

\begin{tabular}{|c|c|c|c|c|c|}
\hline Target gene & Primers sequences & $\begin{array}{c}\text { Amplified } \\
\text { segment (bp) }\end{array}$ & Resistance /virulence * & $\begin{array}{c}\text { Annealing } \\
\text { temperature } \\
\left({ }^{\circ} \mathrm{C}\right)\end{array}$ & Reference \\
\hline \multirow{2}{*}{$q n r A$} & ATTTCTCACGCCAGGATTTG & \multirow{2}{*}{516} & \multirow{2}{*}{ (R) Quinolones } & \multirow{6}{*}{53} & \multirow{6}{*}{ Robicsek et al. (2006) } \\
\hline & GATCGGCAAAGGTTAGGTCA & & & & \\
\hline \multirow{2}{*}{$q n r B$} & GATCGTGAAAGCCAGAAAGG & \multirow{2}{*}{469} & \multirow{2}{*}{ (R) Quinolones } & & \\
\hline & ACGATGCCTGGTAGTTGTCC & & & & \\
\hline \multirow{2}{*}{$q n r S$} & ACGACATTCGTCAACTGCAA & \multirow{2}{*}{417} & \multirow{2}{*}{ (R) Quinolones } & & \\
\hline & TAAATTGGCACCCTGTAGGC & & & & \\
\hline \multirow{2}{*}{$a a c\left(6^{\prime}\right)-I b-c r$} & CCCGCTTTCTCGTAGCA & \multirow{2}{*}{113} & \multirow{2}{*}{ (R) Quinolones } & \multirow{2}{*}{53} & \multirow{2}{*}{ Lunn et al. (2010) } \\
\hline & TTAGGCATCACTGCGTCTTC & & & & \\
\hline \multirow{2}{*}{ qерA } & CGTGTTGCTGGAGTTCTTC & \multirow{2}{*}{403} & \multirow{2}{*}{ (R) Quinolones } & \multirow{2}{*}{50} & \multirow{2}{*}{ Cattoir et al. (2008) } \\
\hline & CTGCAGGTACTGCGTCATG & & & & \\
\hline \multirow{2}{*}{$b l a_{\mathrm{TEM}}$} & ATCAGCAATAAACCAGC & \multirow{2}{*}{516} & & \multirow{2}{*}{54} & \multirow{2}{*}{ Colom et al. (2003) } \\
\hline & CCCCGAAGAACGTTTTC & & Beta-Lactams & & \\
\hline \multirow{2}{*}{$b l a_{\mathrm{CMY}-2}$} & TGGCCAGAACTGACAGGCAAA & \multirow{2}{*}{462} & & \multirow{2}{*}{54} & \multirow{2}{*}{$\begin{array}{l}\text { Pérez-Pérez and } \\
\text { Hanson (2002) }\end{array}$} \\
\hline & TTTCTCCTGAACGTGGCTGGC & & Beta-Lactams & & \\
\hline & ATGTGCAGYACCAGTAARGTKATGGC & & & & Archambault et al. \\
\hline$b l a_{\mathrm{CTX}}$ & TGGGTRAARTARGTSACCAGAAYCAGCGG & 593 & Beta-Lactams & 60 & $(2006)$ \\
\hline & CCTCCCGCACGATGATC & & & & \\
\hline Int1 & TCCACGCATCGTCAGGC & 280 & $\begin{array}{l}\text { Disseminate the } \\
\text { resistance }\end{array}$ & & \\
\hline & TTATTGCTGGGATTAGGC & & & & \\
\hline Int 2 & ACGGCTACCCTCTGTTATC & 250 & $\begin{array}{l}\text { Disseminate the } \\
\text { resistance }\end{array}$ & 50 & Kashif et al. (2013) \\
\hline & AGTGGGTGGCGAATGAGTG & & & & \\
\hline Int3 & TGTTCTTGTATCGGCAGGTG & 484 & $\begin{array}{l}\text { Disseminate the } \\
\text { resistance }\end{array}$ & & \\
\hline hila & CATGGCTGGTCAGTTGGAG & 150 & (V) & 50 & Yano et al (2014) \\
\hline nulA & CGTAATTCATCGCCTAAACG & 150 & (v) & 39 & Yang et al. (2014) \\
\hline Stn & TTGTGTCGCTATCACTGGCAACC & 617 & (V) & 50 & \\
\hline $\operatorname{Stn}$ & ATTCGTAACCCGCTCTCGTCC & $01 /$ & & & Murugkar et al. \\
\hline Pef & TGTTTCCGGGCTTGTGCT & 700 & (V) & 54 & (2003) \\
\hline $\mathrm{Pef}$ & CAGGGCATTTGCTGATTCTTCC & & & 54 & \\
\hline inva & GTGAAATTATCGCCACGTTCGGGCAA & 284 & (V) & 54 & Oliveinget al $(2003)$ \\
\hline & TCATCGCACCGTCAAAGGAACC & 284 & & 54 & Oilvelra et al. (2003) \\
\hline $\operatorname{son} B$ & TCAGAAGRCGTCTAACCACTC & 517 & (V) & 58 & \\
\hline SOPB & TACCGTCCTCATGCACACTC & & & & Huehn et al. (2010) \\
\hline $\operatorname{spv} C$ & ACCAGAGACATTGCCTTCC & 467 & (V) & 60 & \\
\hline$s p v c$ & TTCTGATCGCCGCTATTCG & $40 /$ & (v) & 60 & \\
\hline
\end{tabular}

* The role of the target gene; either antibiotic resistance or virulence activity. (R) means that the target gene is responsible for antibiotic resistance, while (V) means that the target gene is responsible for specific virulence activity of the strain.

\section{RESULTS}

Prevalence and serotyping of Salmonella spp. in CM and PG

According to the results of morphological and biochemical identification of Salmonella isolates, it was found that out of $50 \mathrm{CM}$ samples, 36 samples harbored Salmonella (72\%), while out of 50 PG samples, 32 contained Salmonella $(64 \%)$ (data not shown). The serotyping of 36 and 32 Salmonella isolates from CM and PG revealed that $S$. Infantis represented 52.8 and $50 \%$ in $\mathrm{CM}$ and PG, respectively. While $S$. Kentucky was identified with incidences of 36.1 and $25 \%$ of Salmonella isolates from CM and PG, respectively. Each of $S$. Ferruch and $S$. Kottbus represented $6.25 \%$ of PG isolates, conversely, it was failed to find them in CM. Although, $S$. Colindale represented $5.55 \%$ of $\mathrm{CM}$ Salmonella isolates, it was none in PG. On the other hand, S. Virchow represented 5.55 and $12.5 \%$ in $\mathrm{CM}$ and PG, respectively (Table 2).

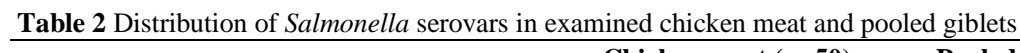

\begin{tabular}{|c|c|c|c|}
\hline \multirow{2}{*}{ Serovars (antigenic formula) } & Chicken meat $(\mathrm{n}=50)$ & Pooled giblets $(n=50)$ & Total $(n=100)$ \\
\hline & No. $(\% *)(\% * *)$ & No. $(\% *)(\% * *)$ & No. $(\% *)(\% * *)$ \\
\hline S. Infantis $\left(\mathrm{O}: 6,7, \underline{14} ; \mathrm{H}_{1}: \mathrm{r} ; \mathrm{H}_{2}: 1,5\right)$ & $19(38)(52.8)$ & $16(32)(50)$ & $35(35)(51.47)$ \\
\hline S. Ferruch $\left(\mathrm{O}: 8 ; \mathrm{H}_{1}: \mathrm{e}, \mathrm{h} ; \mathrm{H}_{2}: 1,5\right)$ & $0(0)(0)$ & $2(4)(6.25)$ & $2(2)(2.94)$ \\
\hline S. Kentucky $\left(\mathrm{O}: 8, \underline{20} ; \mathrm{H}_{1}: \mathrm{i} ; \mathrm{H}_{2}: \mathrm{Z}_{6}\right)$ & $13(26)(36.1)$ & $8(16)(25)$ & $21(21)(30.88)$ \\
\hline S. Kottbus $\left(\mathrm{O}: 6,8 ; \mathrm{H}_{1}: \mathrm{e}, \mathrm{h} ; \mathrm{H}_{2}: 1,5\right)$ & $0(0)(0)$ & $2(4)(6.25)$ & $2(2)(2.94)$ \\
\hline$S$. Virchow $\left(\mathrm{O}: 6,7,14 ; \mathrm{H}_{1}: \mathrm{r} ; \mathrm{H}_{2}: 1,2\right)$ & $2(4)(5.55)$ & $4(8)(12.5)$ & $6(6)(8.82)$ \\
\hline S. Colindale $\left(\mathrm{O}: 6,7 ; \mathrm{H}_{1}: \mathrm{r} ; \mathrm{H}_{2}: 1,7\right)$ & $2(4)(5.55)$ & $0(0)(0)$ & $2(2)(2.94)$ \\
\hline Total Salmonella isolates, no. (\%) & $36(72)$ & $32(64)$ & $68(68)$ \\
\hline
\end{tabular}

Where $\% *$ represents the percentage in relation to the number of examined samples, while $\% * *$ represents the percentage in relation to the number of Salmonella isolates. 


\section{Antibiotic resistance/susceptibility of Salmonella serovars}

The results illustrated in Table 3 show the antibiotic resistance/susceptibility of Salmonella serovars $(n=68)$ isolated from CM and PG. High rates of resistance were explored by the serotyped Salmonella isolates, it was evident that the highest rate of resistance was against nalidixic acid, when all isolates showed resistance against it $(100 \%)$, followed by tetracycline $(89.7 \%)$, cefotaxime $(67.5 \%)$, and then $64.7 \%$ of the isolates were resistant to both ciprofloxacin and ampicillin, followed by ceftazidime $(45.6 \%)$, and amikacin $(35.3 \%)$ comes after, then amoxicillin-clavulanic acid (29.4\%), while the lowest resistance was against each of piperacillin-tazobactam and aztreonam (23.5\%). All isolates of $S$. Virchow $(n=6)$ were resistant to all antibiotics investigated during the study expect piperacillin-tazobactam and aztreonam. Likewise, the two isolates of $S$ Kottbus (100\%) isolated from PG were resistant to all tested antibiotics. Additionally, high levels of resistance were found in $S$. Kentucky, followed by $S$. Infantis and then $S$. Ferruch and $S$. Colindale.

Interestingly, $64.7 \%$ (44 out of 68) of the isolates were resistant to ciprofloxacin which is considered the drug of choice against Salmonella spp. in animals and humans, whereas, the other 24 isolates $(35.3 \%)$ showed intermediate resistance, thus, none of the isolates exhibited any sensitivity to ciprofloxacin. Therefore, we report in the present study the emergence of ciprofloxacin-resistant isolates of $S$. Kentucky (100\%), S. Virchow (100\%), S. Kottbus (100\%), and S. Infantis $(42.8 \%)$ from CM and PG in Egypt (Table 3).

Table 3 Antibiotic resistance of isolated Salmonella serovars from chicken meat and pooled giblets. Antibiotics

Origin/serovars (n) Number of resistant serovars (resistant \%)

\begin{tabular}{|c|c|c|c|c|c|c|c|c|c|c|}
\hline & AK & CIP & AMP & AMC & TZP & CTX & CAZ & ATM & NA & TE \\
\hline Chicken meat (36) & $11(30.6)$ & $24(66.7)$ & $23(63.9)$ & $10(27.8)$ & $9(25)$ & $29(80.6)$ & $17(47.2)$ & $8(22.2)$ & $36(100)$ & $33(91.7)$ \\
\hline S. Infantis (19) & $5(26.3)$ & $9(47.4)$ & $6(31.6)$ & $0(0)$ & $3(15.8)$ & $15(78.9)$ & $3(15.8)$ & $2(10.5)$ & $19(100)$ & $18(94.7)$ \\
\hline S. Kentucky (13) & $4(30.8)$ & $13(100)$ & $13(100)$ & $8(61.5)$ & $6(46.15)$ & $12(92.3)$ & $12(92.3)$ & $6(46.2)$ & $13(100)$ & $13(100)$ \\
\hline S. Virchow (2) & $2(100)$ & $2(100)$ & $2(100)$ & $2(100)$ & $0(0)$ & $2(100)$ & $2(100)$ & $0(0)$ & $2(100)$ & $2(100)$ \\
\hline$S$. Colindale (2) & $0(0)$ & $0(0)$ & $2(100)$ & $0(0)$ & $0(0)$ & $0(0)$ & $0(0)$ & $0(0)$ & $2(100)$ & $0(0)$ \\
\hline Pooled giblets (32) & $13(46.6)$ & $20(62.5)$ & $21(65.6)$ & $10(31.3)$ & 7 (21.9) & 23 (71.9) & $14(43.8)$ & $8(25)$ & $32(100)$ & $28(87.5)$ \\
\hline S. Infantis (16) & $4(25)$ & $6(37.5)$ & $5(31.3)$ & $0(0)$ & $2(12.5)$ & $11(68.8)$ & $2(12.5)$ & $2(12.5)$ & $16(100)$ & $14(87.5)$ \\
\hline$S$. Ferruch (2) & $0(0)$ & $0(0)$ & $2(100)$ & $0(0)$ & $0(0)$ & $0(0)$ & $0(0)$ & $0(0)$ & $2(100)$ & $0(0)$ \\
\hline$S$. Kentucky (8) & $3(37.5)$ & $8(100)$ & $8(100)$ & $4(50)$ & $3(37.5)$ & $6(75)$ & $6(75)$ & $4(50)$ & $8(100)$ & $8(100)$ \\
\hline S. Kottbus (2) & $2(100)$ & $2(100)$ & $2(100)$ & $2(100)$ & $2(100)$ & $2(100)$ & $2(100)$ & $2(100)$ & $2(100)$ & $2(100)$ \\
\hline$S$. Virchow (4) & $4(100)$ & $4(100)$ & $4(100)$ & $4(100)$ & $0(0)$ & $4(100)$ & $4(100)$ & $0(0)$ & $4(100)$ & $4(100)$ \\
\hline Total sensitive (\%) & $36(52.9)$ & $0(0)$ & $13(19.1)$ & $32(47.1)$ & $24(35.3)$ & $14(20.6)$ & $27(39.7)$ & $39(57.3)$ & $0(0)$ & $7(10.3)$ \\
\hline Total intermediate $(\%)$ & $8(11.8)$ & $24(35.3)$ & $11(16.2)$ & $16(23.5)$ & $28(41.2)$ & $2(2.9)$ & $10(14.7)$ & $13(19.2)$ & $0(0)$ & $0(0)$ \\
\hline Total resistant (\%) & $24(35.3)$ & $44(64.7)$ & $44(64.7)$ & $20(29.4)$ & $16(23.5)$ & $52(67.5)$ & $31(45.6)$ & $16(23.5)$ & $68(100)$ & $61(89.7)$ \\
\hline
\end{tabular}

AK (amikacin $30 \mu \mathrm{g}$ ), CIP (ciprofloxacin $5 \mu \mathrm{g}$ ), AMP (ampicillin $10 \mu \mathrm{g}$ ), AMC (amoxicillin-clavulanic acid 20/10 $\mu \mathrm{g}$ ), TZP (piperacillin-tazobactam 100/10 $\mu \mathrm{g}$ ), CTX (cefotaxime $30 \mu \mathrm{g}$ ), CAZ (ceftazidime $30 \mu \mathrm{g}$ ), ATM (aztreonam $30 \mu \mathrm{g}$ ), NA (nalidixic acid $30 \mu \mathrm{g}$ ), and TE (tetracycline $30 \mu \mathrm{g}$ ).

\section{Integron profile and antibiotic resistance genes}

The data illustrated in Table 4 clarify the antibiotic resistance pattern, integron profile (classes $1,2 \& 3$ ) and antibiotic resistance-associated genes in 13 isolates which were selected from MDR Salmonella serovars isolated from CM and PG. The selected 13 isolates showed variable degrees of MDR which ranged from 0.2 (resistant to 2/10 antibiotics) to one (resistant to 10/10 antibiotics). Integron class 1 was detected in $100 \%$ of the isolates, while integron class 3 existed in $92.3 \%$ of the isolates. Interestingly, the only isolate that had not integron 3 showed the lowest MDR pattern (0.2). On the contrary, integron class 2 was absent in all isolates $(0 \%)$.

Regarding plasmid-mediated quinolone resistance (PMQR) genes, it was surprising that the three most significant $q n r$ genes ( $q n r A$, $q n r B$ and $q n r S$ ) were absent in all molecularly identified isolates, and $a a c\left(6^{\prime}\right)-I b-c r$ and $q e p A$ either. However, $53.8 \%$ and $100 \%$ of the isolates were found resistant to ciprofloxacin and nalidixic acid, respectively (Table 4).

Concerning $\beta$-lactams resistance-related genes, bla $a_{\mathrm{TEM}}, b l a_{\mathrm{CMY}-2}$ and $b l a_{\mathrm{CTX}}$ were found in $100 \%, 30.7 \%$ and $53.8 \%$ of the isolates, respectively (Table 4).

Table 4 Resistance pattern, integron classes (1,2 and 3) and antibiotic resistance genes among MDR Salmonella serovars isolated from chicken meat $(\mathrm{CM})$ and pooled giblets $(\mathrm{PG})$

\begin{tabular}{|c|c|c|c|c|c|c|c|c|c|c|}
\hline \multirow{2}{*}{ No. } & \multirow{2}{*}{$\begin{array}{l}\text { Serovar } \\
\text { (Origin) }\end{array}$} & \multirow{2}{*}{ Resistance pattern } & \multirow{2}{*}{$\begin{array}{l}\text { MDR } \\
\text { ratio }\end{array}$} & \multicolumn{3}{|c|}{ Integron profile } & \multicolumn{4}{|c|}{ Antibiotic resistance genes } \\
\hline & & & & Int1 & Int2 & Int3 & PMQR genes & $b^{b l a} a_{\mathrm{TEM}}$ & bla $_{\mathrm{CMY}-2}$ & $b l a_{\mathrm{CTX}}$ \\
\hline 1 & Kentucky (CM) & $\begin{array}{l}\text { AK, CIP, AMP, AMC, TZP, CTX, CAZ, } \\
\text { ATM, NA, TE }\end{array}$ & 1 & + & - & + & - & + & + & - \\
\hline 2 & Kentucky (PG) & CIP, AMP, CTX, CAZ, NA, TE & 0.6 & + & - & + & - & + & + & - \\
\hline 3 & Kentucky (CM) & $\begin{array}{l}\text { CIP, AMP, AMC, TZP, CTX, CAZ, NA, } \\
\text { TE }\end{array}$ & 0.8 & + & - & + & - & + & + & - \\
\hline 4 & Infantis $(\mathrm{CM})$ & CTX, NA, TE & 0.3 & + & - & + & - & + & + & - \\
\hline 5 & Virchow (CM) & $\begin{array}{l}\text { AK, CIP, AMP, AMC, CTX, CAZ, NA, } \\
\text { TE }\end{array}$ & 0.8 & + & - & + & - & + & - & + \\
\hline 6 & Kentucky (CM) & CIP, AMP, NA, TE & 0.4 & + & - & + & - & + & - & + \\
\hline 7 & Infantis (PG) & AK, NA, TE, CTX & 0.4 & + & - & + & - & + & - & + \\
\hline 8 & Infantis (CM) & NA, TE, CTX & 0.3 & + & - & + & - & + & - & + \\
\hline 9 & Infantis $(\mathrm{CM})$ & $\begin{array}{l}\text { CIP, AMP, TZP, CTX, CAZ, ATM, NA, } \\
\text { TE }\end{array}$ & 0.8 & + & - & + & - & + & - & - \\
\hline 10 & Infantis $(\mathrm{CM})$ & CIP, CTX, NA, TE & 0.4 & + & - & + & - & + & - & + \\
\hline 11 & Infantis (PG) & AK, AMP, NA, TE & 0.4 & + & - & + & - & + & - & + \\
\hline 12 & Infantis (CM) & AK, AMP, CTX, NA, TE & 0.5 & + & - & + & - & + & - & + \\
\hline 13 & Infantis (PG) & NA, TE & 0.2 & + & - & - & - & + & - & - \\
\hline
\end{tabular}

AK (amikacin $30 \mu \mathrm{g}$ ), CIP (ciprofloxacin $5 \mu \mathrm{g}$ ), AMP (ampicillin $10 \mu \mathrm{g}$ ), AMC (amoxicillin-clavulanic acid 20/10 $\mu \mathrm{g}$ ), TZP (piperacillin-tazobactam 100/10 $\mu \mathrm{g}$ ), CTX (cefotaxime $30 \mu \mathrm{g}$ ), CAZ (ceftazidime $30 \mu \mathrm{g}$ ), ATM (aztreonam $30 \mu \mathrm{g}$ ), NA (nalidixic acid $30 \mu \mathrm{g}$ ), and TE (tetracycline $30 \mu \mathrm{g}$ ). $\mathrm{CM}$ : chicken meat, PG: pooled giblets. MDR ratio (multiple drug resistance ratio), for instance, MDR 0.6 means that this strain was resistance to 6 out of 10 antibiotics tested $(6 / 10=0.6)$. PMQR genes, plasmid-mediated quinolone resistance genes $\left(q n r A, q n r B, q n r S, a a c\left(6^{\prime}\right)-I b-c r\right.$ and $\left.q e p A\right)$. 


\section{Molecular identification of virulence-associated genes}

The results of molecular identification of virulence genes in 13 MDR isolates of Salmonella were illustrated in Table 5. The data showed that each of the invasion gene invA, the hyper invasive locus hilA and $\operatorname{sopB}$ gene were detected in all isolates $(100 \%)$. While, stn gene was found $94.7 \%$. Conversely, the plasmidencoded fimbria (pef) locus was not detected in any of the identified isolates, as well as the other plasmid-located virulence gene $s p v C$ was distinguished in only one out of 13 isolates.

Table 5 Virulence genes among MDR Salmonella serovars isolated from chicken meat $(\mathrm{CM})$ and pooled giblets (PG).

\begin{tabular}{llcccccc}
\hline \multirow{2}{*}{ No. } & \multirow{2}{*}{ Serovar (Origin) } & \multicolumn{7}{c}{ Virulence genes } \\
\cline { 3 - 7 } & invA & hilA & Stn & Pef & sopB & spvC \\
\hline 1 & Kentucky (CM) & + & + & + & - & + & - \\
\hline 2 & Kentucky (PG) & + & + & + & - & + & - \\
\hline 3 & Kentucky (CM) & + & + & + & - & + & - \\
\hline 4 & Infantis (CM) & + & + & + & - & + & - \\
\hline 5 & Virchow (CM) & + & + & + & - & + & - \\
\hline 6 & Kentucky (CM) & + & + & + & - & + & - \\
\hline 7 & Infantis (PG) & + & + & + & - & + & + \\
\hline 8 & Infantis (CM) & + & + & + & - & + & - \\
\hline 9 & Infantis (CM) & + & + & + & - & + & - \\
\hline 10 & Infantis (CM) & + & + & + & - & + & - \\
\hline 11 & Infantis (PG) & + & + & + & - & + & - \\
\hline 12 & Infantis (CM) & + & + & + & - & + & - \\
\hline 13 & Infantis (PG) & + & + & - & - & + & - \\
\hline
\end{tabular}

\section{DISCUSSION}

The surprisingly higher rates of Salmonella spp. in the present study than previous reports (Ammar et al., 2016; Gharieb et al., 2015) could be attributed to the slaughter of live birds inside the poultry retail markets with absence of veterinary supervision and without even a minimum hygienic measure during different stages of carcass preparation, processing, and handling. Additionally, cross contamination from workers, equipment and utensils used during carcass preparation could be very important source of contamination (Antunes et al. 2016).

Although, $S$. Typhimurium has not been detected in the present study, it was determined as a predominant serovar in poultry meat in some previous studies in other areas in Egypt such as Gharieb et al. (2015). It could be attributed to the difference in the location of sample collection in the current study, as to the best of our knowledge, this is the first study to emphasize the prevalence of Salmonella serovars in retail poultry meat in Beni-Suef, Egypt. Alternatively, $S$. Infantis and $S$. Kentucky were reported as predominant Salmonella serovars in poultry meat in the present study. Incidentally, $S$. Infantis is capable of triggering septicemia and death in both children and adults (Fonseca, 2006). As well as, the European Food Safety Authority and European Centre for Disease Prevention and Control (EFSA and ECDC, 2015) denoted that $S$. Infantis is the second most predominant serovar in broiler meat and the fourth most dominant one in human non-typhoidal salmonellosis in Europe. Regarding S. Kentucky, Weill et al. (2006) detected $197 \mathrm{~S}$. Kentucky isolates in French travelers during 2000 through 2005, among them 17 ciprofloxacin-resistant strains were detected in 16 patients got the infection during or instantly after travel to Egypt (10 patients), Kenya, Tanzania, and Sudan. Consistent with the current result, Weill et al. (2006) reported that poultry is the main animal reservoir of $S$. Kentucky. Concerning to $S$. Virchow, the third highly reported serovar in this study, however it causes mild infection in humans, it produces severe illness in immunocompromised persons; therefore, the European Union has given it a priority for control of entry the food chain (Arnold, 2010)

Resistance to ciprofloxacin has been reported exceptionally in nontyphoidal Salmonella isolates and only in S. Typhimurium, $S$. Choleraesuis, and $S$. Schwarzengrund (Weill et al., 2006). Fascinatingly, we report in the present study the emergence of ciprofloxacin-resistant isolates of $S$. Kentucky (100\%), $S$ Virchow (100\%), S. Kottbus (100\%), and S. Infantis (42.8\%) from CM and PG in Egypt, which is considered the drug of choice against Salmonella infection in animals and humans (CLSI, 2018). Conferring the last report of EFSA and ECDC (2016) on antibiotic resistance in zoonotic and indicator bacteria from humans, animals and food, $S$. Infantis significantly contributed to the overall numbers of MDR Salmonellae in Europe, when isolates from broilers showed resistance to third generation cephalosporins and great resistance to ciprofloxacin. Therefore, a high worry still leftovers for the public health significance of $S$. Infantis. It was proposed that the routine practice of using antimicrobials in food animal and poultry production is engaged in the emergence of antibiotic resistant bacterial strains and are subsequently transferred to human beings through the food chain (Stürenburg and Mack, 2003; Threlfall, 2002).
As regard to integrons, in accordance with the present study, the previous report of Siriken (2015) concluded that class 1 is the most widely spread and clinically reported integron in MDR Salmonellae. Worthy mentioning that integron containing isolates are more antibiotic resistant than those lacking integrons (Fluit AC, Schmitz, 2004), alike this study. Quinolones are very significant antibiotic substances for overcoming bacterial infections in both animals and humans, thus quinolone resistance is considered a noteworthy public health risk. The high quinolones-resistance rate (ciprofloxacin and nalidixic acid) of Salmonella serovars reported in the present study, despite absence of quinolones resistance-related genes indicates that other determinants could be encountered A similar scenario was reported by Myšková and Íšková (2017). This could be explained considering the concepts of Jacoby (2005) who suggested that quinolone resistance is mostly attributed to mutation in chromosomes that modify the antibiotic target enzymes, DNA gyrase ( $g y r A$ and $g y r B$ ) and DNA topoisomerase IV (parC and parE) or trigger the efflux systems. Moreover, according to Piddock (1999), a single point mutation in gyrA can arbitrate resistance to the nonfluorinated quinolone $(100 \%$ of the identified isolates in the present study showed resistance to nalidixic acid) and reduce susceptibility to fluoroquinolones $(53.8 \%$ of the identified isolates in the present study showed resistance to ciprofloxacin), while mutation in the gyrB, parC and parE is rare in Salmonella (Eaves et al., 2004). In addition to quinolones resistance, the antibiotic resistance to expanded spectrum cephalosporines, which are strongly recommended for the treatment of salmonellosis, is determined mainly by the existence of extended spectrum $\beta$-lactamases (ESBL) and plasmid-mediated AmpC $\beta$-lactamases (PABL) genes of which bla $a_{\mathrm{TEM}}, b l a_{\mathrm{CTX}}$ and $b l a_{\mathrm{CMY}-2}$ are the most common (Kang et al., 2013). This explains the high level of antibiotic resistance to that group in the present study, as 61.5, 23.0, 23.0, 76.9, 38.4, and $15.3 \%$ of the isolates were resistant to ampicillin, amoxicillin-clavulanic acid, piperacillin-tazobactam, cefotaxime, ceftazidime and aztreonam from $\beta$-lactams group, respectively.

In addition to the antibiotic resistance, the existence of invA, hilA, sopB and sth virulence genes in almost all MDR Salmonella isolates indicates the high pathogenicity of these isolates to animal, poultry and humans. Since invA and hilA genes are responsible for penetration of Salmonella bacterium into the host cells (Valdez et al., 2009; Lostroh et al., 2000). While $\operatorname{sop} B$, in addition to its role in host cell membrane invasion, is also responsible for rearrangement of the host cell cytoskeletons (Borges et al., 2013). As well as, stn gene is in charge of production of enterotoxins and is linked to triggering acute gastroenteritis in infected hosts (Zou et al., 2012). Consequently, the retail chicken meat marketed in Egypt constitutes high public health risks to consumers. Thus, it should be faced with a high level of care and consideration by the legal authorities.

\section{CONCLUSION}

In conclusion, the high rate of Salmonellae in the present study is attributed to the slaughter of live birds without veterinary supervision inside low hygienic poultry retail markets. $S$. Infantis and $S$. Kentucky are the top among the mostly isolated Salmonella enterica serovars from poultry meat in Egypt. The emergence of ciprofloxacin-resistant isolates of $S$. Kentucky, $S$. Virchow, $S$. Kottbus, and $S$ Infantis from CM and PG was reported for the first time in Egypt. Isolates with class 1 integron showed a high level of MDR. Class 2 was absent in all isolates. The determined high rate of quinolones-resistance of Salmonella serovars, despite absence of quinolones resistance-related genes, indicates that other genetic factors could be incriminated. The high level of resistance to $\beta$-lactams is attributed to the high incidence of $\beta$-lactams resistance-related genes (bla $a_{\mathrm{TEM}}$ $b l a_{\mathrm{CMY}-2}$ and $\left.b l a_{\mathrm{CTX}}\right)$. Eventually, the existence of high incidence of virulence genes within MDR Salmonella serovars gives us an alarm and should be faced with a great worry because consumers could be under a great public health risk.

\section{REFERENCES}

Ammar, A. M., Mohamed, A. A., El-Hamid, M. I. A., El-Azzouny, M. M. 2016 Virulence genotypes of clinical Salmonella Serovars from broilers in Egypt. The Journal of Infection in Developing Countries, 10(04), 337-346. DOI: https://doi.org/10.3855/jidc. 7437

Antunes, P., Mourão, J., Campos, J., Peixe, L. 2016. Salmonellosis: the role of poultry meat. Clinical Microbiology and Infection, 22(2), 110-121. https://doi.org/10.1016/j.cmi.2015.12.004

Archambault, M., Petrov, P., Hendriksen, R. S., Asseva, G., Bangtrakulnonth, A., Hasman, H., Aarestrup, F. M. 2006. Molecular characterization and occurrence of extended-spectrum $\beta$-lactamase resistance genes among Salmonella enterica serovar Corvallis from Thailand, Bulgaria, and Denmark. Microbial Drug Resistance, 12, 192-198. https://doi.org/10.1089/mdr.2006.12.192

Arnold, M.E., Papadopoulou, C., Davies, R.H., Carrique-Mas, J.J., Evans, S.J., Hoinville, L.J.2010. Estimation of Salmonella prevalence in UK egg-laying holdings. Preventive Veterinary Medicine, 94,306-309. https://doi.org/10.1016/j.prevetmed.2010.01.004

Bhunia, A.2007. Foodborne microbial pathogens: mechanisms and pathogenesis. USA: Springer. https://doi.org/10.1007/978-1-4939-7349-1 
Borges, K.A., Furian, T.Q., Borsoi, A., Moraes, H.L., Salle, C.T., Nascimento, V.P. 2013. Detection of virulence-associated genes in Salmonella Enteritidis isolates from chicken in South of Brazil. Pesquisa Veterinaria Brasileira ,33,1416-1422. http://dx.doi.org/10.1590/S0100-736X2013001200004

Cambray, G., Guerout, A.M., Mazel, D. 2010. Integrons. Annual Review of Genetics, 44, 141-166. https://doi.org/10.1146/annurev-genet-102209-163504 Cattoir, V., Poirel, L., Nordmann, P. 2008. Plasmid-mediated quinolone resistance pump QepA2 in an Escherichia coli isolate from France. Antimicrobia Agents and Chemotherapy, 52, 3801-3804. https://DOI:10.1128/AAC.00638-08 CLSI (Clinical and laboratory Standards Institute) 2018. Performance Standards for Antimicrobial Susceptibility Testing; $28^{\text {th }}$ Edition. CLSI document M100 Ed28. Wayne, P.A.: Clinical and laboratory Standards Institute, Wayne, Pennsylvania, USA. Available on: https://clsi.org/standards/products/microbiology/documents/m100/. Last accessed on October $24^{\text {th }}-2018$.

Colom, K., Pèrez,J., Alonso, R., Fernández-Aranguiz, A., Lariňo, E.,Cisterna, R. 2003. Simple and reliable multiplex PCR assay for detection of $b l a_{\mathrm{TEM}}, b l a_{\mathrm{SHV}}$ and $b l a_{\mathrm{OXA}-1}$ genes in Enterobacteriaceae. FEMS Microbiology Letters, 223, 147 151. https://doi.org/10.1016/S0378-1097(03)00306-9

Eaves, D.J., Randall, L., Gray, D.T., Buckley, A., Woodward, M.J., White, A.P., Piddock, L.J.V.2004. Prevalence of Mutations within the Quinolone ResistanceDetermining Region of gyrA, gyrB, parC, and parE and Association with Antibiotic Resistance in Quinolone-Resistant Salmonella enterica. Antimicrobial $\begin{array}{llll}\text { Agents and Chemotherapy, 4012-4015. } & \end{array}$ https://DOI:10.1128/AAC.48.10.4012-4015.2004

EFSA and ECDC (European Food Safety Authority and European Centre for Disease Prevention and Control) 2013.The European Union summary report on trends and sources of zoonoses, zoonotic agents and food-borne outbreaks in 2011. EFSA Journal, 11, 3129. https://doi.org/10.2903/j.efsa.2013.3129

EFSA and ECDC (European Food Safety Authority and European Centre for Disease Prevention and Control) 2015. The European Union Summary Report on Trends and Sources of Zoonoses, Zoonotic Agents and Food-borne Outbreaks in 2013. EFSA Journal, 13,3991. https://doi.org/10.2903/j.efsa.2015.3991

EFSA and ECDC (European Food Safety Authority and European Centre for Disease Prevention and Control) 2014. The European Union summary report on antimicrobial resistance in zoonotic and indicator bacteria from humans, animals and food in 2014. EFSA Journal 2016, 14,4380 https://doi.org/10.2903/j.efsa.2016.4380

Fluit, A.C., Schmitz, F.J. 2004. Resistance integrons and superintegrons. Clinical Microbiology and Infection, 10, 272-288 https://doi.org/10.1111/j.1198-743X.2004.00858.x

Fonseca, E.L., Mykytczuk, O.L., Asensi, M.D., Reis, E.M.F., Ferraz, L.R., Paula, F.L., L. K. Ng, Rodrigues, D.P. 2006. Clonality and antimicrobial resistance gene profiles of multidrug-resistant Salmonella enterica serovar Infantis isolates from four public hospitals in Rio de Janeiro, Brazil. Journal of Clinical Microbiology ,44, 2767-2772. https://DOI:10.1128/JCM.01916-05

Friedrich, M.J., Kinsey, N.E., Vila, J., Kadner, R.J. 1993. Nucleotide sequence of a $13.9 \mathrm{~kb}$ segment of the $90 \mathrm{~kb}$ virulence plasmid of Salmonella typhimurium: the presence of fimbriai biosynthetic genes. Molecular Microbiology, 8, 543-558. https://doi.org/10.1111/j.1365-2958.1993.tb01599.x

Gharieb, R.M., Tartor, Y.H., Khedr, M.H. 2015. Non-Typhoidal Salmonella in poultry meat and diarrhoeic patients: prevalence, antibiogram, virulotyping, molecular detection and sequencing of class I integrons in multidrug resistant strains. Gut Pathogens, 7, 34. https://doi.org/10.1186/s13099-015-0081-1

Hassan, A.-R. H., Salam, H. S., \& Abdel-Latef, G. K. (2016). Serological identification and antimicrobial resistance of Salmonella isolates from broiler carcasses and human stools in Beni-Suef, Egypt. BSU Journal of Basic and Applied Sciences, 5(2), 202-207. https://doi.org/10.1016/j.bjbas.2016.04.002 Huehn, S., La Ragione, R.M., Anjum, M., Saunders, M., Woodward, M.J., Bunge, C., Helmuth, R., Hauser, E., Guerra, B., Beutlich, J., Brisabios, A., Peters, T., Svensson, L., Madajczak, G., Litrup, E., Imre, A., Herrera-Leon, S., Mevius, D., Newell, D. G. \& Malorny, B. 2010. Virulotyping and antimicrobial resistance typing of Salmonella enterica serovars relevant to human health in Europe. Foodborne Pathogens and Diseases, 7, 523-535 https://doi.org/10.1089/fpd.2009.0447

ISO 6579, 2002. Microbiology of food and animal feeding stuffs-horizonta method for the detection of Salmonella spp. Geneva: International Organization for Standardization. Available on: https://www.iso.org/standard/29315.html. Last accessed on October $24^{\text {th }}-2018$.

Jacoby, G.A. 2005. Mechanism of resistance to quinolones. Clinical Infectious Diseases, 41, S120 - S126. https://doi.org/10.1086/428052

Kang, M.S., Kwon, Y.K., Oh, J.Y., Kim, M.J., Call, D.R., An, B.K., Shin, E.G., Song, E.A., Kwon, J.H. 2013. Evidence for recent acquisition and successful transmission of bla (CTX-M-15) in Salmonella enterica in South Korea Antimicrobial Agents and Chemotherapy, 57,2383-2387. https://DOI:10.1128/AAC.01854-12

Kashif, J., Buriro, R., Memon, J., Yaqoob, M., Soomro, J., Dongxue, D., Jinhu, H., Liping, W. 2013. Detection of Class 1 and 2 Integrons, $\beta$-Lactamase Genes and Molecular Characterization of Sulfonamide Resistance in Escherichia coli
Isolates Recovered from Poultry in China. Pakistan Veterinary Journal, 33, 321 324.

Lostroh, C.P., Bajaj, V., Lee, C.A.2000. The cis requirements for transcriptional activation by hilA, a virulence determinant encoded on SPI-1. Molecular Microbiology, 37,300-315. https://doi.org/10.1046/j.1365-2958.2000.01991.x

Lunn, A. D., Fàbrega, A., Sánchez-Céspedes, J., Vila, J. 2010. Prevalence of mechanisms decreasing quinolone-susceptibility among Salmonella spp. clinical isolates. International https://DOI:10.2436/20.1501.01.107

Murugkar, H. V., Rahman, H., Dutta, P. K. 2003. Distribution of virulence genes in Salmonella serovars isolated from man \& animals. Indian Journal of Medical Research, 117, 66-70.

Myšková, P. E. T. R. A., Íšková, R. K. 2017. Prevalence and Characteristics of Salmonella in Retail Poultry and Pork Meat in the Czech Republic in 2013 2014. Czech Journal of Food Science, 35(2). https://doi:10.17221/260/2016-CJFS Oliveira, S. D., Rodenbusch, C. R., Ce, M. C., Rocha, S. L. S., Canal, C. W. 2003. Evaluation of selective and non-selective enrichment PCR procedures for Salmonella detection. Letters in Applied Microbiology, 36, 217-221. https://doi.org/10.1046/j.1472-765X.2003.01294.X

Pérez-Pérez, F. J., Hanson, N. D. 2002. Detection of plasmid-mediated AmpC $\beta$ lactamase genes in clinical isolates by using multiplex PCR. Journal of Clinica Microbiology, 40, 2153-2162. https://DOI:10.1128/JCM.40.6.2153-2162.2002

Popoff, M.Y., Bockemuhl, J., Gheesling, L.L. 2004. Supplement 2002 (no. 46) to the Kauffmann-White scheme. Research in Microbiology, 155:568-70 https://doi.org/10.1016/j.resmic.2004.04.005

Piddock, L.J.V.1999. Mechanisms of fluoroquinolone resistance: an update 1994-1998. Drugs, 58 (2),11-18. https://doi.org/10.2165/00003495-19995800200003

Robicsek, A., Strahilevitz, J., Jacoby, G.A., Macielag, M., Abbanat, D., Park C.H., Bush, K., Hooper, D.C.2006. Fluoroquinolone-modifying enzyme: a new adaptation of a common aminoglycoside acetyltransferase. Nature Medicine, 12 83-88. https://doi.org/10.1038/nm1347

Siriken, B., Türk, H., Yildirim, T., Durupinar, B., Erol, I. 2015. Prevalence and characterization of Salmonella isolated from chicken meat in Turkey. Journal of Food Science, 80 (5), M1044-M1050. https://doi.org/10.1111/1750-3841.12829 Stürenburg, E., \& Mack, D. (2003). Extended-spectrum $\beta$-lactamases implications for the clinical microbiology laboratory, therapy, and infection control. Journal of Infection, 47, 273-295. https://doi.org/10.1016/S0163 4453(03)00096-3

Threlfall, E.J. (2002). Antimicrobial drug resistance in Salmonella: problems and perspectives in food- and water-borne infections. FEMS Microbiology Reviews 26, 141-148. https://doi.org/10.1111/j.1574-6976.2002.tb00606.x

Valdez, Y., Ferreira, R.B., Finlay, B.B.2009. Molecular mechanisms of Salmonella virulence and host resistance. In: Molecular Mechanisms of Bacterial Infection via the Gut. Current Topics in Microbiology and Immunology. Berlin Heidelberg: Springer, pp. 93-127. https://doi.org/10.1007/978-3-642-01846-6_4 Weill, F.X., Bertrand, S., Guesnier, F., Baucheron, S., Grimont, P.A.D., Cloeckaert, A. 2006. Ciprofloxacin-resistant Salmonella Kentucky in travelers [letter]. Emerging Infectious Diseases,12,1611-1612. doi [10.3201/eid1210.060589]

Wiesner, M., Calva, J. J., Bustamante, V. H., Pérez-Morales, D., FernándezMora, M., Calva, E., Silva, C. 2016. A multi-drug resistant Salmonella Typhimurium ST213 human-invasive strain (33676) containing the bla CMY-2 gene on an IncF plasmid is attenuated for virulence in BALB/c mice. BMC Microbiology, 16(1), 18. https://doi.org/10.1186/s12866-016-0633-7

Yang, X., Huang, J., Wu, Q., Zhang, J., Liu, S., Guo, W., Cai, S., Yu, S. 2016. Prevalence, antimicrobial resistance and genetic diversity of Salmonella isolated from retail ready-to-eat foods in China, Food Control, 6,50-56. https://doi.org/10.1016/j.foodcont.2015.07.019

Yang, X., Brisbin, J., Yu, H., Wang, Q., Yin, F., Zhang, Y., Sabour, P., Sharif, S., Gong, J. 2014. Selected Lactic Acid-Producing Bacterial Isolates with the Capacity to Reduce Salmonella Translocation and Virulence Gene Expression in Chickens. PloS one, 9, 4, e93022. https://doi.org/10.1371/journal.pone.0093022 Zou, M., Keelara, S., Thakur, S. 2012. Molecular characterization of Salmonella enterica serotype Enteritidis isolates from humans by antimicrobial resistance, virulence genes, and pulsed field gel electrophoresis. Foodborne Pathogens and Diseases, 9, 232- 238. https://doi.org/10.1089/fpd.2011.1012 